\title{
Let's be pals again: major systematic changes in Palaemonidae (Crustacea: Decapoda)
}

Sammy De Grave, Charles HJM Fransen, Timothy J Page

In recent years the systematic position of genera in the shrimp families Gnathophyllidae and Hymenoceridae has been under debate, with phylogenetic studies suggesting the families are not real family level units. Here, we review the molecular evidence as well as the morphological characters used to distinguish both families, leading to the conclusion that neither family is valid. Further, we studied the structural details of the single morphological character which distinguishes the two subfamilies (Palaemoninae, Pontoniinae) in Palaemonidae, as well as their phylogenetic relationship. As the supposed character distinction plainly does not hold true and supported by the phylogenetic results, the recognition of subfamilies in Palaemonidae is not warranted. As a consequence, all three supra-generic taxa (Gnathophyllidae, Hymenoceridae, Pontoniinae) are thus herein formally synonymised with Palaemonidae. 


\section{Let's be pals again: major systematic changes in Palaemonidae (Crustacea: Decapoda)}

3 Sammy De Grave ${ }^{1}$, Charles H.J.M. Fransen ${ }^{2}$ and Timothy J. Page ${ }^{3,4}$

$5{ }^{1}$ Oxford University Museum of Natural History, Parks Road, Oxford, OX1 3PW, United 6 Kingdom.

$7 \quad 2$ Department of Marine Zoology, Naturalis Biodiversity Center, P.O. Box 9517, 2300 RA

8 Leiden, The Netherlands.

$9{ }^{3}$ Australian Rivers Institute, Faculty of Environmental Sciences, Griffith University, Nathan

10 Campus, Qld 4111, Australia.

114 Water Planning Ecology, Queensland Dept. of Science, Information Technology and 12 Innovation, Dutton Park, QLD, 4102, Australia.

\section{ABSTRACT}

15 In recent years the systematic position of genera in the shrimp families Gnathophyllidae and Hymenoceridae has been under debate, with phylogenetic studies suggesting the families are not real family level units. Here, we review the molecular evidence as well as the morphological characters used to distinguish both families, leading to the conclusion that neither family is valid. Further, we studied the structural details of the single morphological character which distinguishes the two subfamilies (Palaemoninae, Pontoniinae) in Palaemonidae, as well as their phylogenetic relationship. As the supposed character distinction plainly does not hold true and supported by the phylogenetic results, the recognition of subfamilies in Palaemonidae is not warranted. As a consequence, all three supra-generic taxa (Gnathophyllidae, Hymenoceridae, Pontoniinae) are thus herein formally synonymised with Palaemonidae.

Key words: Molecular phylogenetics, telson, systematics, synonymy, Gnathophyllidae, Hymenoceridae, Pontoniinae 
In recent years, the higher level of systematics of caridean shrimps has seen considerable changes at subfamily, family and superfamily level, but not without controversy. To take but one example, Bracken et al. (2009) suggested that the family Oplophoridae could be polyphyletic, however this study only included 4 genera (out of 10). This was followed by Chan et al. (2010) who, on the basis of a molecular phylogeny of 10 species from 9 genera, split the family into two families, Oplophoridae and Acanthephyridae, underpinned by habitat and morphological differences between the two families. However, Wong et al. (2015) in a more comprehensive study of 30 species in 9 genera, consider the family to be monophyletic, yet comprising two distinct clades, which correspond to the above separate families. Finally, AznarCormano et al. (2015) in a wide-ranging analysis with coverage across all caridean families, recovered both families as distinct lineages with high support, but with poorly resolved relationships between them.

Despite such problems, currently 39 families of caridean shrimps are recognised (De

Grave \& Fransen, 2011; Baeza et al., 2014; De Grave et al., 2014). Seven of these families used to be placed in the superfamily Palaemonoidea Rafinesque, 1815 (see De Grave \& Fransen, 2011), namely Anchistioididae Borradaile, 1915; Desmocarididae Borradaile, 1915; Euryrhynchidae Holthuis, 1950; Gnathophyllidae Dana, 1852; Hymenoceridae Ortmann, 1890; Palaemonidae Rafinesque, 1815 and Typhlocarididae Annandale \& Kemp, 1913. In previous classifications (e.g. De Grave et al., 2009; De Grave \& Fransen, 2011) a further family was recognised, Kakaducarididae Bruce, 1993. Following the phylogenetic analysis in Page et al. (2008), Short et al. (2013) in a morphological reappraisal relegated this family to the synonymy of Palaemonidae. Although Palaemonoidea at superfamily level appears to indeed form a monophyletic group ( $\mathrm{Li}$ et al., 2011), superfamilies are not often formally used any more in caridean systematics, and we herein refer to this assemblage of families as the palaemonoid clade. Traditionally, Palaemonidae has been thought to comprise two subfamilies, Palaemoninae Rafinesque, 1815 (primarily freshwater and temperate coastal species) and Pontoniinae Kingsley, 1879 (primarily tropical species, most abundant on coral reefs), although the morphological

60 dividing line between both can be rather arbitrary (Bruce, 1995). 
In common with several other taxa, the systematic composition of the palaemonoid clade

62

has been somewhat mired in controversy in recent decades. It was not until Chace (1992) that Hymenoceridae were recognised as separate from Gnathophyllidae. In contrast, Typhlocarididae was comprised of two subfamilies in his classification, Typhlocaridinae and Euryrhynchinae, therein followed by the major compilations of Chace \& Bruce (1993) and Holthuis (1993). Bruce (1993) expressed the opinion that both these taxa are not closely related and should be treated as independent families, a view corroborated by the morphological discussion in De Grave (2007).

Mitsuhashi et al. (2007) were the first to demonstrate that Gnathophyllidae, Hymenoceridae and Pontoniinae form a paraphyletic clade in their $18 \mathrm{~S} / 28 \mathrm{~S}$ analysis of a limited dataset (only including 17 species from four families) and pointed out the congruence of larval morphology to this result. Kou et al. (2013a) expanded on this dataset (16S/18S/28S), with 44 species ( 7 families), but with heavy bias towards Palaemoninae (only 2 Pontoniinae were included). Despite this unbalanced sampling scheme, their results demonstrate Palaemoninae to be polyphyletic and the same paraphyletic assemblage of Gnathophyllidae, Hymenoceridae and Pontoniinae. Recently, Gan et al. (2015) provided yet one more variant, based on a combined analysis of $16 \mathrm{~S} / \mathrm{H} 3 / \mathrm{Nak} /$ Enolase, with a heavy inclusion of Pontoniinae over Palaemoninae (as well as Gnathophyllidae, Hymenoceridae, Anchistioididae), but exclusive of the Atlantic families, Desmocarididae, Euryrhynchidae and Typhlocarididae. Nevertheless, their analysis once again recovers Gnathophyllidae and Hymenoceridae inside Pontoniinae. Despite this wealth of data, analyses to date have not included the full breadth of available molecular diversity within the palaemonoid clade as a whole, thus any systematic conclusions are at best partial, and at worst misleading. This has, in part, been due to the fact that different loci have often been sequenced for the different taxa, making a comparison between them impossible. We have trawled through available molecular data to assemble datasets that represent the lion's share of the currently available molecular diversity within each of the nine suprageneric palaemonoid taxa ( 7 families, 2 subfamilies) so as to assess the relationships amongst them with fullest possible data.

The systematic distinction of the two subfamilies within Palaemonidae, i.e. Palaemoninae and Pontoniinae, has received scant scrutiny and has been generally followed without query. To date, no phylogenetic study has included sufficient taxa from both to allow a discussion of the 
92 validity of either subfamily. Morphologically, they are distinguished on a single character, of 93 somewhat dubious validity. Kingsley (1879) distinguished both taxa on the basis of the 94 presence/absence of a mandibular palp (therein followed by Spence Bate, 1888), a clearly 95 variable character within each subfamily (see Chace \& Bruce, 1993; De Grave \& Ashelby, 96 2013). Sollaud (1910) distinguished both taxa on the basis of the presence/absence of a 97 pleurobranch on the third thoracic somite, to which Balss (1957) added the ornamentation of the 98 posterior telson. Abele \& Felgenhauer (1986), as well as Bruce (1995) showed the absence of a 99 pleurobranch on the third maxilliped in selected species of Macrobrachium. Further, Bruce 100 (2002) demonstrated variability in the size of the arthrobranch, which is reduced in Leander 101 manningi. We therefore concur with Bruce (1995) that it is likely that both Palaemoninae and

102 Pontoniinae have five pairs of pleurobranchs, leaving only the telson distinction. Holthuis (1993) 103 defined the latter as follows: telson with two pairs of posterior "spines" and with one or more 104 pairs of hairs (i.e. plumose setae) - Palaemoninae, versus telson usually with three pairs of 105 posterior "spines" - Pontoniinae. However, Bruce (1995) drew attention to the fact that in many 106 Pontoniinae, the submedian "spines" are often also plumose. In the present contribution, we 107 provide a detailed morphological examination of these setae, in combination with molecular 108 analyses to investigate the relationships of the two subfamilies.

\section{MATERIAL AND METHODS}

Dataset construction for molecular analysis

114 Genbank (www.ncbi.nlm.nih.gov) was searched for sequences of palaemonoid taxa on 24

115 November, 2014. We were looking for genetic markers for which there were data from all seven 116 palaemonoid families (Anchistioididae, Desmocarididae, Euryrhynchidae, Gnathophyllidae,

117 Hymenoceridae, Palaemonidae, Typhlocarididae) and for which there was also good coverage of 118 genera of the two subfamilies within Palaemonidae (Palaemoninae, Pontoniinae). In particular, 119 we strove to include the various clades and divergent taxa within each subfamily as identified in 120 previous restricted subfamily studies (Ashelby et al., 2012; Kou et al., 2013b; Gan et al., 2015). 121 We only included species for which there were at least two different independent markers. It 122 quickly became apparent that some loci were available only for one subfamily (e.g., Pontoniinae 
123 - Enolase, NaK, Pepck), and so were not informative across all taxa. The four markers that had

124 the best coverage across all taxa were the mitochondrial 5' cytochrome $c$ oxidase I (COI),

125 mitochondrial 16S ribosomal DNA (16S), nuclear Histone 3 (H3) and nuclear 18S ribosomal

126 DNA (18S). Preliminary analyses of COI data quickly established that although it was effective

127 at grouping very closely related species, it was highly ineffective at inferring deeper systematic

128 relationships, which is unsurprising given its relatively rapid rate of molecular divergence. Thus,

129 we settled on $16 \mathrm{~S}, \mathrm{H} 3$ and $18 \mathrm{~S}$ for our analyses, as this combination of markers with differing

130 levels of divergence may pull out any strong systematic relationships.

131 Relevant data from GenBank, and an additional three new H3 sequences of our own

132 (Gnathophylloides mineri, Manipontonia psamathe, Pontonia manningi) were combined (Table

133 1), with the alpheid Betaeus longidactylus as an outgroup. Sequences of the three markers were

134 imported into Mega 6 (Tamura et al., 2013) and each aligned separately using Muscle (Edgar,

135 2004) within Mega. The most appropriate substitution model (lowest Bayesian Information

136 Criterion score) was chosen with Mega. Four separate datasets were created; 16S (424 base pairs

137 [bp], 45 species); H3 (327 bp, 42 species); 18S (1559 bp, 23 species), combined 16S/H3/18S

138 (2310 bp, 45 species), with any unavailable data coded as missing (Table 1).

139

140 Molecular analyses

141

142 The single marker datasets were analysed using Bayesian analyses in MrBayes 3.2 (Ronquist et 143 al. 2012) and Maximum Likelihood in Mega (bootstrapped 1000 times), both using the relevant

144 molecular model for each marker. The Bayesian analyses were done using the following

145 parameters: 5 million generations, trees sampled every 1000 cycles, $25 \%$ burn in, two runs of

146 four chains heated to 0.2. The combined dataset was analysed using Bayesian analyses as above.

$147 \quad$ Formal phylogenetic support for various systematic schemes was assessed by

148 constraining the topology of the Bayesian analyses in the relevant way and then rerunning

149 MrBayes for each dataset. Constrained versus unconstrained harmonic means of log likelihood

150 values were then compared with Bayes Factors (Kass \& Rafter, 1995). Seven different

151 topological constraints were tested (the last 5 only on the combined dataset), with no constraints

152 place on topologies within each defined clade unless specified: 
153 A) species of Palaemoninae form a clade, and species of Pontoniinae form a separate clade; B) 154 species of Palaemoninae form one clade, and species of Gnathophyllidae/ Hymenoceridae/

155 Pontoniinae form a separate single clade; C) species of Palaemonidae/ Gnathophyllidae/

156 Hymenoceridae form a clade; D) Palaemonidae form a clade, and within it both Palaemoninae 157 and Pontoniinae are reciprocally monophyletic (effectively the current state of play); E)

158 Palaemonidae form a clade, and within it Palaemoninae forms a clade sister to a clade of

159 Pontoniinae/ Gnathophyllidae/ Hymenoceridae; F) species of Anchistioididae/ Palaemonidae/

160 Gnathophyllidae/ Hymenoceridae form one clade; G) species of Desmocarididae/

161 Euryrhynchidae/ Palaemonidae/ Gnathophyllidae/ Hymenoceridae form a clade.

162

163 Morphological study

164

165 Twelve species (Table 2) were selected randomly from Palaemoninae (4 species) and

166 Pontoniinae ( 8 species) to investigate the posterior ornamentation of the telson, which currently

167 is the only morphological character which distinguishes both subfamilies. Tissue preparation for

168 Scanning Electron Microscopy (SEM) follows De Grave \& Wood (2011), whereby tissue is

169 hydrated to distilled water via a series of graded ethanol solutions, briefly sonicated using a light

170 surfactant and dehydrated in graded ethanol to $100 \%$. Drying was achieved using the HMDS

171 method, and specimens coated with a gold-palladium mixture using an E5000 sputter coater.

172 Mounted specimens were observed and photographed using a JEOL JSM-5510 microscope;

173 images were not post processed with image software. SEM observations were complemented by

174 light microscopy of a much wider range of species to verify the results. Setal terminology in

175 general follows Garm (2004), although we consider the term cuspidate to also include more

176 elongated forms of setae termed "intermediate form between cuspidate and simple" in Garm

177 (2004) to facilitate discussion.

178

\section{RESULTS}

180

181

Molecular Results

182 
183 Bayesian (BA) trees were produced for the combined dataset (Fig. 1, Figs. S1-2), as well as 184 Bayesian and Maximum Likelihood (ML) trees for each single locus dataset (Figs. S3-8).

185 Majority rule consensus trees are displayed for Bayesian trees (i.e. clades $>0.50$ posterior 186 probability). BA and ML analyses inferred similar clades at shallower levels for the single 187 marker datasets, with ML support values generally lower. Our analyses are primarily based on 188 the combined dataset, with the single locus analyses provided for reference.

Typhlocarididae

191 Typhlocarididae was represented by two of the three markers (16S, 18S). Its sole genus was 192 recovered strongly as sister to all other palaemonoids (Fig. 1). Both its 16S and 18S sequences 193 were highly differentiated from the rest of the sampled Palaemonoidea.

Anchistioididae

The two species from the sole anchistioidid genus (Anchistioides) formed a strong clade in all analyses. Its relationship with the other families (excluding Typhlocarididae) is not immediately apparent. It did not form strong clades with the other families in most analyses, except in both 18S analyses where it groups with Palaemonidae, Gnathophyllidae and Hymenoceridae to the exclusion of Desmocarididae and Euryrhynchidae. However when Anchistioididae was constrained to form a clade with Palaemonidae/ Gnathophyllidae/ Hymenoceridae in a combined analysis (Constraint F), its score was slightly worse than when Desmocarididae and Euryrhynchidae were constrained to form a clade with Palaemonidae/ Gnathophyllidae/ Hymenoceridae (Constraint G) (Table 3), so its precise relationship with the other families is unclear.

Desmocarididae and Euryrhynchidae

208 Desmocarididae and Euryrhynchidae were represented by two of the three markers (16S, 18S).

209 They formed a strong clade with each other (Fig. 1), in particular due to their 18S data, but their 210 relationship to the other families (except Typhlocarididae) is unclear in the same way as

211 Anchistioididae above. They may be sister to Anchistioididae/ Palaemonidae/ Gnathophyllidae/

212 Hymenoceridae (Fig. S2), however the tree score when they are forced to form a clade with

213 Palaemonidae/ Gnathophyllidae/ Hymenoceridae to the exclusion of Anchistioididae (Constraint 
214 G) is marginally better than when Anchistioididae is constrained to Palaemonidae/

215 Gnathophyllidae/ Hymenoceridae (Constraint F) (Table 3), however the difference is not great,

216 and neither constraint produces a particularly bad score relative to the unconstrained analysis.

217 Therefore the relationship of the clade formed by Desmocarididae/ Euryrhynchidae is unclear

218 relative to Anchistioididae/ Palaemonidae/ Gnathophyllidae/ Hymenoceridae. However, when

219 constraints are applied to other taxa (Constraints B, C), Anchistioididae forms a strong clade

220 with palaemonid taxa to the exclusion of Desmocarididae/ Euryrhynchidae (Figs. S1-2), so it is

221 possible that Desmocarididae/ Euryrhynchidae is sister to Anchistioididae/ Palaemonidae/

222 Gnathophyllidae/ Hymenoceridae, but more data is required to explore this further.

223

224 Palaemonidae

225 As currently defined a pure Palaemonidae is not supported as a distinct separate unit (Constraint

226 D) since Gnathophyllidae and Hymenoceridae clearly nest within, making Palaemonidae

227 paraphyletic at best (Fig. 1). However when one includes Gnathophyllidae and Hymenoceridae

228 within Palaemonidae and does not enforce monophyly of the subfamilies, then there is little

229 difference compared to completely unconstrained analyses (Constraint C). Even when

230 Palaemoninae and Pontoniinae/ Gnathophyllidae/ Hymenoceridae are constrained to be sisters

231 within a monophyletic Palaemonidae, the resulting tree score is not really too much worse

232 (Constraint E, Table 3). This implies that the "problem" is with the internal structure of

233 Palaemonidae rather than in its relationship to others, and that it may well be a monophyletic

234 unit. However as stated above, it is also unclear how Desmocarididae/ Euryrhynchidae, and

235 particularly Anchistioididae, relate to Palaemonidae. Plainly Palaemonidae contains

236 Gnathophyllidae and Hymenoceridae. However, it is not yet clear phylogenetically whether

237 Palaemonidae is truly monophyletic relative to Anchistioididae and/or Desmocarididae/

238 Euryrhynchidae, within Palaemonoidea.

239

240 Palaemoninae and Pontoniinae

241 I Palaemoninae and Pontoniinae do not form clear monophyletic clades in any of our analyses.

242 When they are each constrained to monophyly (Constraint A), the scores are all very much worse

243 than when unconstrained (Table 3). When Gnathophyllidae and Hymenoceridae are considered

244 honorary Pontoniinae (Constraint B), then the tree scores improved markedly in all analyses 
245 (Table 3) (Fig. S1), but the evidence against this topology is still very strong. When

246 Palaemoninae and Pontoniinae are constrained to clades within a monophyletic Palaemonidae

247 (Constraint D), which is essentially the current taxonomy, the scores are very poor and so are

248 unlikely to reflect phylogenetic reality. However when Gnathophyllidae and Hymenoceridae are

249 included within Pontoniinae within a monophyletic Palaemonidae (Constraint E), then scores

250 improve greatly, although still worse than unconstrained. The one constraint that approaches the

251 unconstrained scores is when all species of Palaemoninae, Pontoniinae, Gnathophyllidae and

252 Hymenoceridae are thrown together into a single clade but without any intraclade constraints

253 (Constraint C) (Fig. S2).

254 Instead of a clear delineation of reciprocally monophyletic Palaemoninae and Pontoniinae

255 (which includes Gnathophyllidae/ Hymenoceridae), what emerges are a number of larger clades

256 that contain either species of Palaemoninae or species of Pontoniinae/ Gnathophyllidae/

257 Hymenoceridae, and a few divergent species of Palaemoninae whose relationship is unclear (Fig.

258 1). However these clades and species do not form larger clades that equate to the subfamilies as

259 currently defined.

260

Morphology of the posterior margin of the telson in Palaemonidae

262

263 The posterior margin of the telson in the majority of Palaemoninae comprises a lateral pair of 264 short cuspidate setae, a submedian pair of elongated, cuspidate setae and one or more pairs of 265 median plumose setae (Fig. 2A, C, E). The plumose setae are classical in structure, with two 266 rows of long setules, weakly articulated with the setal shaft (Fig. 2B, D). Although the examples 267 shown herein (Palaemon adspersus, Macrobrachium amazonicum, Leander tenuicornis) only

268 have a single pair of median plumose setae, several other taxa harbour two (e.g. Brachycarpus 269 biunguiculatus) or more pairs (e.g. Neopalaemon nahuatlus, Palaemon tonkinensis). As

270 exemplified herein by Palaemon modestus (Fig. 2F), deviations of this bauplan exist, with the

271 species previously assigned to Exopalaemon (recently transferred to Palaemon), having lost the 272 median plumose setae.

273 Although the extensive bauplan modification in Pontoniinae due to their extensive 274 commensal relationships has resulted in more variation in the ornamentation of the posterior 275 margin of the telson, many genera remain morphologically very similar in this respect to 
276 Palaemoninae. For example, the free living Palaemonella rotumana (Fig. 3A-B) and Cuapetes 277 americanus (Fig. 3C-D) have a similar arrangement with a pair of lateral cuspidate setae, a 278 submedian pair of elongated, cuspidate setae and a median pair of plumose setae. The median 279 plumose setae are however more robust than their counterparts in Palaemoninae, with sparser 280 and somewhat shorter setules. In some commensal taxa, the submedian pair of cuspidate setae is 281 considerably shorter, as exemplified herein by the anemone associate, Periclimenes brevicarpalis 282 (Fig. 3E) and the sponge associate Periclimenaeus caraibicus (Fig. 3F). Both, however, harbour 283 a robust pair of median plumose setae, with somewhat shorter and sparser setules. In contrast, 284 rather densely plumose median setae are evident in the coral dwelling Jocaste lucina (Fig. 4A-B) 285 and the sponge associated Thaumastocaris streptopus (Fig. 4C-D), with the setules in both being 286 as long as in Palaemoninae. In the morphologically highly modified, echinoid associated 287 Stegopontonia commensalis, the median setae are very robust, but continue to display a reduced 288 set of setules, both sparse (mainly restricted to basal part) and very short (Fig. 4E). A barely 289 discernible set of minute setules is still present on the median setae in the equally highly 290 modified, bivalve associate, Conchodytes nipponensis (Fig. 4F), which otherwise has only two 291 pairs of extremely short and robust cuspidate setae, homologous to the median and submedian 292 pairs in the other species.

293

294

295

296

297 The numerous molecular analyses presented herein agree strongly in some respects, but agree 298 only weakly in some, and even disagree in others. Therefore it is not always possible to come to unequivocal conclusions in all cases, but our overall hypothesis of relationships, based on the current molecular analyses in the palaemonoid clade is presented in Figure 5. Available data suggests strongly that Typhlocarididae are a sister group to the rest of Palaemonoidea. Next, there is weak evidence that a clade of Desmocarididae/ Euryrhynchidae are a sister group to the remaining taxa, however this is not certain. Anchistioididae may form a clade with Palaemonidae/ Gnathophyllidae/ Hymenoceridae, either as sister or within the clade itself. There is very strong evidence that Gnathophyllidae and Hymenoceridae form a clade within Palaemonidae. 
There is also strong molecular evidence that Palaemoninae and Pontoniinae do not form

308

309

310

311

312

313

314

315

316

317

318

319

320

321

322

323

324

325

326

327

328

329

330

331

332

333

334

335

336

337

reciprocally monophyletic clades. Even when Gnathophyllidae and Hymenoceridae are considered as part of Pontoniinae, the evidence against this is strong, however the evidence against legitimate clades of Palaemoninae and Pontoniinae/ Gnathophyllidae/ Hymenoceridae is reduced markedly. Because of this, and because there are few instances when some species of Palaemoninae and Pontoniinae form strong clades with each other relative to others from their respective subfamilies, it remains possible that the addition of more markers and taxa could theoretically bring together reciprocal monophyletic clades that equate to Palaemoninae and Pontoniinae/ Gnathophyllidae/ Hymenoceridae. This does not however seem particularly likely. Our molecular results mirror those of Mitsuhashi et al. (2007), Kou et al. (2013a) and Gan et al. (2015), who each recover a paraphyletic clade comprising the family Palaemonidae and Gnathophyllidae/Hymenoceridae. As already discussed by Mitsuhashi et al. (2007), this relationship is underpinned by similarities in larval morphology. Bruce (1986) when describing the first zoea of Gnathophyllum americanum already remarked that they are fundamentally pontoniine in nature, and further highlighted the uniformity in larval form within Palaemonidae sensu lato when he described the zoea of Hymenocera picta (see Bruce, 1988). Recently, Meyer et al. (2014) also commented on the close morphological similarity between gnathophyllids, hymenocerids and pontoniines when describing the fine features under SEM of the zoea of Gnathophyllum elegans.

As regards the adults, Holthuis $(1955,1993)$ and Chace (1992) characterised both Gnathophyllidae and Hymenoceridae by the mandible with a vestigial or absent incisor process, third maxilliped being broadened, at least proximally (sometimes operculate) and the first maxilliped with the caridean lobe not distinctly overreaching the endite. The other palaemonoid families are therein jointly defined primarily by the slender third maxilliped and the mandible usually with a prominent incisor. Ample evidence exists that the vestigial or absent incisor is not a synapomorphy of these families. Bruce (1986) already commented that some species in the pontoniine genera Periclimenaeus, Onycocaris and Typton also lack an incisor, for example Typton gnathophylloides (see Holthuis, 1951, Plate 50). Conversely, some gnathophyllids, like Pycnocaris chagoae, harbour a rudimentary incisor (see Bruce, 1972, Fig 5A.). In fact, even in Gnathophyllum elegans, the type species of the family Gnathophyllidae, a vestigial incisor is present (see Ashelby et al., 2015, Fig. 5A). Although the third maxilliped is markedly operculate 
338 in Gnathophyllum, this is not the case for all gnathophyllid genera. The third maxilliped in 339 Gnathophylloides is broadened, but not operculate (see Bruce, 1973, Fig. 4C), whilst only

340 basally broadened in Levicaris (see Bruce, 1973, Fig. 8G). Conversely, some pontoniine genera

341 equally have a much broadened third maxilliped, notably members of the genus Conchodytes

342 (see Fransen, 1994, Figs. 35-37). The extensive bauplan modifications of the first maxilliped in

343 pontoniine shrimps makes a comparison futile, perhaps the reason why this character distinction

344 was not listed in the latest definition of the families by Wicksten (2010). It should be noted that

345 both Hymenocera and Phyllognathia do share a unique synapomorphy amongst palaemonoid

346 shrimps, namely the basis of the third maxilliped being distinct from the ischiomerus, which in

347 turn is marked by a distinct suture, delineating the ischium and merus. Both Chace (1992) and

348 Holthuis (1993) used this character to separate the Hymenoceridae from the Gnathophyllidae.

349 The current molecular analysis, as well as those of Mitsuhashi et al. (2007), Kou et al. (2013a)

350 and Gan et al. (2015) do demonstrate this not to be of familial importance.

351 In view of the overwhelming molecular evidence, the similarity in larval morphology and

352 the weak morphological basis on which to separate adults into their respective families,

353 Gnathophyllidae Dana, 1852 and Hymenoceridae Ortmann, 1890 are thus herein formally

354 synonymised with Palaemonidae Rafinesque, 1815. As a result, the genera Gnathophylleptum

355 d'Udekem d'Acoz, 2001, Gnathophylloides Schmitt, 1933, Gnathophyllum Latreille, 1819,

356 Levicaris Bruce, 1973, and Pycnocaris Bruce, 1972 (all formerly in Gnathophyllidae), as well as

357 Hymenocera Latreille, 1819 and Phyllognathia Borradaile, 1915 (both formerly in

358 Hymenoceridae), and their constituent species (see De Grave \& Fransen, 2011 for a listing) are

359 now to be considered genera in Palaemonidae.

360 Our molecular analyses do not recover the two subfamilies within Palaemonidae, viz.

361 Palaemoninae and Pontoniinae as reciprocally monophyletic clades. Instead, there appear to be

362 at least two clades of Pontoniinae species (Clades I and II as per Kou et al., 2013b; Gan et al.,

363 2015), including the ex-gnathophyllid and hymenocerid genera in Clade II, and yet these two

364 clades of Pontoniinae do not necessarily form a clade with each other (Fig. 1). Within

365 Palaemoninae, there is generally one large strongly supported clade of species (here called

366 palaemonid Clade III) (Fig. 1), which usually includes a couple more divergent species

367 (Palaemon concinnus, Palaemon elegans). There are also a number of species of Palaemoninae

368 which do not form a clade with other members of the subfamily, namely Brachycarpus 
biunguiculatus, Nematopalaemon tenuipes, and a clade of Leander tenuicornis/Urocaridella

370

371

372

373

374

375

376

377

378

379

380

381

382

383

384

385

386

387

388

389

390

391

392

393

394

395

396

397

398

399

pulchella. When species of Palaemonidae are constrained to a clade without subfamily constraints, Leander tenuicornis/ Urocaridella pulchella and Nematopalaemon tenuipes form a clade with the pontoniine Clade I (Fig. S2). These results do mirror the actual trees presented in Kou et al. (2013a) which equally do not show the two subfamilies to form monophyletic clades, although not discussed therein. Earlier, Bracken et al. (2009) had already hinted at the fact that the family as then defined was either para- or polyphyletic and the position of several pontoniine genera in their analysis was at odds with their current classification.

As already mentioned, the sole morphological character on which placement of a given genus in their respective subfamily is based is the ornamentation of the posterior margin of the telson, specifically the cuticular extensions. The terminology of these structures has been confusing in taxonomic descriptions, variously referred to as "spines", "stout setae", "spiniform setae". Herein, we adhere to the definition of Watling (1989) that a "spine" is a non-articulated, cuticular extension, with a "seta" being articulated, although we do acknowledge that nonarticulated setae exist (see Garm \& Watling, 2013), but these do not enter the discussion here. Following the classification of setal types by Garm (2004), it is clear (Figs. 2-4) that the plesiomorphic condition in the family Palaemonidae comprises of a lateral pair of cuspidate setae, a submedian pair of elongated cuspidate setae and a median (or more) pair of plumose setae. Variations on this theme abound, with the median pair of plumose setae being thin and long to short(er) and stout, but nevertheless with a clear double row of poorly articulated setules on the shaft, thus still fitting the definition of plumose setae. In some taxa (Fig. 4E-F), the setules are reduced and the general appearance of the setae approaches that of cuspidate setae. Although cuspidate setae are known to occasionally have small outgrowths on their shaft, these are in the shape of denticles (Garm, 2004; Garm \& Watling, 2013). We therefore interpret these median setae as reduced plumose setae.

Of course, concomitant with the rich bauplan diversity of pontoniine and palaemonine taxa, more variation exists than herein illustrated. For example, in Hamopontonia, the distal margin of the telson is emarginated and devoid of cuspidate and plumose setae; instead a number of simple setae are present (see Bruce, 1970) and in Yeminicaris, the distal margin is broadly rounded and devoid of cuspidate and plumose setae (see Bruce, 1997). A further example is illustrated in Fig. 10F, Palaemon modestus, where the median plumose setae are absent, the latter 
400 being characteristic for species of Palaemon previously considered to be a separate genus, 401 Exopalaemon (see De Grave \& Ashelby, 2013).

402 Nevertheless, from the evidence presented herein (Figs. 2-4) it is abundantly clear that 403 the sole morphological character separating the two subfamilies does not hold true. In light of 404 this, and supported by the molecular analyses, the subfamilies Palaemoninae Rafinesque 1815 405 and Pontoniinae Kingsley, 1879 are herein formally synonymised and subfamilies are thus no 406 longer recognised in Palaemonidae Rafinesque, 1815.

$407 \quad$ As in previous analyses (Mitsuhashi et al., 2007; Bracken et al., 2009; Kou et al., 2013a; 408 Gan et al., 2015) the position of Anchistiodidae remains uncertain, although it is clear that the 409 family is closely related to Palaemonidae as herein defined. Historically the sole genus in this 410 family, Anchistioides was often considered to be in Pontoniinae (now Palaemonidae), for 411 instance by Kemp (1922), Gordon (1935) and Holthuis (1955). In more recent treatments, 412 following Chace (1992) separate familial status has been the norm. Chace \& Bruce (1993) 413 remarked that the genus differs little from some pontoniines, separated only by seemingly minor 414 adult morphological characters, but as pointed out by Chace (1992) and Chace \& Bruce (1993), 415 the larvae, described by Gurney $(1936,1938)$ differ sufficiently to support a separate family. As 416 we cannot clarify the position of the genus Anchistioides, we refrain from analysing the 417 morphological evidence and leave the family Anchistioididae as valid, until further evidence 418 becomes available.

\section{ACKNOWLEDGEMENTS}

421

422 Bregje W. Brinkmann and Cessa Rauch (Naturalis Biodiversity Centre) are acknowledged for 423 sequencing the $\mathrm{H} 3$ genes of Gnatophylloides mineri, Manipontonia psamathe and Pontonia 424 manningi.

\section{REFERENCES}

Abele LG, Felgenhauer BE. 1986. Phylogenetic and phenetic relationships among the lower 429 Decapoda. Journal of Crustacean Biology 6: 385-400. 
430 431

Ashelby CW, De Grave S, Johnson ML. 2015. Preliminary observations on the mandibles of palaemonoid shrimp (Crustacea: Decapoda: Caridea: Palaemonoidea). PeerJ 3: e846.

Ashelby CW, Page TJ, De Grave S, Hughes JM, Johnson ML. 2012. Regional scale speciation drives multiple invasions of freshwater in Palaemoninae (Decapoda). Zoologica Scripta 41:293-306.

Aznar-Cormano L, Brisset J, Chan TY, Corbari L, Puillandre N, Utge J, Zbinden M, Zuccon D, Samadi S. 2015. An improved taxonomic sampling is a necessary but not sufficient condition for resolving inter-families relationships in Caridean decapods. Genetica 143: 195-205.

Baeza JA, Bauer RT, Okuno J, Thie, M. 2014. Molecular phylogeny of hinge-beak shrimps (Decapoda: Caridea: Rhynchocinetes and Cinetorhynchus) and allies: a formal test of familiar and generic monophyly using a multilocus phylogeny. Zoological Journal of the Linnean Society 172: 426-450.

Balss H. 1957. Decapoda VIII Systematik. In: Gruner HE, ed. Dr H.G. Bronns klassen und ordungen des tierreichs. Fünfter Band, I. Abteilung. Buch 7 Lieferung 12. Leipzig: Akademische Verlagsgesellschaft, 1505-1672.

Bracken HD, De Grave S, Felder DL. 2009. Phylogeny of the infraorder Caridea based on mitochondrial and nuclear genes (Crustacea: Decapoda). In: Martin JW, Crandall KA, Felder DL, eds. Decapod Crustacean Phylogenetics. Boca Raton, London, New York: CRC Press, Taylor \& Francis Group, 281-305.

Bruce AJ. 1970. Notes on some Indo-Pacific Pontoniinae. XV. Hamopontonia corallicola gen. nov., sp. nov., a new pontoniid shrimp from Hong Kong. Crustaceana 18: 37-48.

Bruce AJ. 1972. Pycnocaris chagoae gen. nov., sp. nov., a new shrimp from the Chagos Archipelago (Decapoda Natantia, Gnathophyllidae). Crustaceana 23: 50-64.

Bruce AJ. 1973. Gnathophylloides robustus sp. nov., a new commensal gnathophylloid shrimp from Western Australia, with the designation of a new genus Levicaris (Decapoda, Caridea). Crustaceana 24: 17-32.

Bruce AJ. 1986. Observations on the family Gnathophyllidae Dana, 1852 (Crustacea: Decapoda). Journal of Crustacean Biology 6: 463-470. 
459

460

461

462

463

464

465

466

467

468

469

470

471

472

473

474

475

476

477

478

479

480

481

482

483

484

485

486

487

488

Bruce AJ. 1988. A note on the first zoeal stage larva of Hymenocera picta Dana (Crustacea: Decapoda: Palaemonidae). The Beagle, Records of the Northern Territory Museum of Arts and Sciences 5: 119-124.

Bruce AJ. 1993. Kakaducaris glabra gen. nov., sp. nov., a new freshwater shrimp from the Kakadu National Park, Northern Territory, Australia, Crustacea: Decapoda: Palaemonidae with the designation of a new subfamily Kakaducaridinae. Hydrobiologia 268: $27-44$.

Bruce AJ. 1995. A synopsis of the Indo-West Pacific genera of the Pontoniinae (Crustacea: Decapoda: Pontoniinae). Theses Zoologicae 25: 1-172 [imprint 1994, published 16 March 1995].

Bruce AJ. 1997. A new pontoniine shrimp genus (Crustacea :Decapoda) from the Yemen, with a note on other species. Journal of Natural History 31:1213-1222.

Bruce AJ. 2002. Leander manningi, a new palaemonine shrimp from Western Australia (Crustacea, Decapoda, Palaemonidae), with a review of the Indo-West Pacific species of the genus Leander E.Desmarest, 1849. Records of the Western Australian Museum 21: $71-81$.

Chace FAJr. 1992. On the classification of the Caridea (Decapoda). Crustaceana 63: 70-80.

Chace FAJr, Bruce AJ. 1993. The caridean shrimps (Crustacea: Decapoda) of the Albatross Philippine Expedition 1907-1910, Part 6: Superfamily Palaemonoidea. Smithsonian Contributions to Zoology 543: 1-152.

Chan TY, Lei HC, Li CP, Chu KH. 2010. Phylogenetic analysis using rDNa reveals polyphyly of Oplophoridae (Decapoda: Caridea). Invertebrate Systematics 24: 172-181.

De Grave S. 2007. A new species of Euryrhynchus Miers, with a discussion of the systematic position of the Euryrhynchidae Holthuis (Crustacea, Decapoda). Zoologischer Anzeiger 246: 193-203.

De Grave S, Ashelby CW. 2013. A re-appraisal of the systematic status of selected genera in Palaemoninae (Crustacea: Decapoda: Palaemonidae). Zootaxa 3734: 331-344.

De Grave S, Fransen CHJM. 2011. Carideorum Catalogus: The recent species of the dendrobranchiate, stenopodidean, procarididean and caridean shrimps (Crustacea: Decapoda). Zoologische Mededelingen 85: 195-589. 
489

490

491

492

493

494

495

496

497

498

De Grave S, Wood L. 2011. Further occurrences of tegumental scales in caridean shrimps (Crustacea: Decapoda: Caridea). Crustacean Research 40: 41-50.

De Grave S, Li CP, Tsang LM, Chu KH, Chan, TY. 2014. Unweaving hippolytoid systematics (Crustacea, Decapoda, Hippolytidae): resurrection of several families. Zoologica Scripta 43: 496-507.

De Grave S, Pentcheff ND, Ahyong ST, Chan TY, Crandall KA, Dworschak PC, Felder DL, Feldmann RM, Fransen CHJM, Goulding LYD, Lemaitre R, Low MEY, Martin JW, Ng PKL, Schweitzer CE, Tan SH, Tshudy D, Wetzer R. 2009. A classification of living and fossil genera of decapod crustaceans. Raffles Bulletin of Zoology Suppl. 21:1-109.

Edgar RC. 2004. MUSCLE: multiple sequence alignment with high accuracy and high throughput Nucleic Acids Research 32:1792-1797.

Fransen CHJM. 1994. Marine palaemonoid shrimps of the Netherlands Seychelles Expedition 1992-1993. Zoologische Verhandelingen 297: 85-152.

Gan Z, Li X, Kou Q, Chan T, Chu K, Huang H. 2015. Systematic status of the caridean families Gnathophyllidae Dana and Hymenoceridae Ortmann (Crustacea: Decapoda): a further examination based on molecular and morphological data. Chinese Journal of Oceanology and Limnology 33: 149-158.

Garm A. 2004. Revising the definition of the crustacean seta and setal classification systems based on examinations of the mouthpart setae of seven species of decapods. Zoological Journal of the Linnean Society 142: 233-252.

Garm A, Watling L. 2013. The crustacean integument: Setae, setules, and other ornamentation. In: Watling L, Thiel M, eds. The Natural History of the Crustacea. Vol. 1, Functional morphology and diversity. Oxford: Oxford University Press, 167-198.

Gordon I. 1935. On new and imperfectly known species of Crustacea Macrura. The Journal of the Linnean Society.Zoology 39: 307-351.

Gurney R. 1936 Notes on some decapod Crustacea of Bermuda. III. The larvae of the Palaemonidae. Proceedings of the Zoological Society of London 1936: 619-623.

Gurney R. 1938. The larvae of the decapod Crustacea, Palaemonidae and Alpheidae. Great Barrier Reef Expedition, 1928-1929, Scientific Reports 6: 1-60. 
518 Holthuis LB 1951. A general revision of the Palaemonidae (Crustacea Decapoda Natantia) of the

519

520

521

522

523

524

525

526

527

528

529

530

531

532

533

534

535

536

537

538

539

540

541

542

543

544

545

546

547

548

Americas. I. The subfamilies Euryrhynchidae and Pontoniinae. Occasional Papers of the Allan Hancock Foundation 11: 1-332.

Holthuis LB 1955. The recent genera of the caridean and stenopodidean shrimps (Class Crustacea, order Decapoda, supersection Natantia) with keys for their determination. Zoologische Verhandelingen 26: 1-157.

Holthuis LB. 1993. The recent genera of the caridean and stenopodidean shrimps (Crustacea, Decapoda) with an appendix on the order Amphionidacea. Leiden: Nationaal Natuurhistorisch Museum.

Kass RE, Raftery AE. 1995. Bayes factors. Journal of the American Statistical Association 90: 773-795.

Kemp S. 1922. Notes on Crustacea Decapoda in the Indian Museum, XV. Pontoniinae. Records of the Indian Museum 24: 113-288.

Kingsley JS. 1879. List of the North American Crustacea belonging to the suborder Caridea. Bulletin of the Essex Institute 10 (for 1878); 53-71.

Kou Q, Li X, Chan TY, Chu KH, Gan Z. 2013a. Molecular phylogeny of the superfamily Palaemonoidea (Crustacea: Decapoda: Caridea) based on mitochondrial and nuclear DNA reveals discrepancies with the current classification. Invertebrate Systematics 27: $502-514$.

Kou Q, Li X, Chan TY, Chu KH, Huang H, Gan Z. 2013b. Phylogenetic relationships among genera of the Periclimenes complex (Crustacea: Decapoda: Pontoniinae) based on mitochondrial and nuclear DNA. Molecular Phylogenetics and Evolution 68: 14-22.

Li CP, De Grave S, Chan TY, Lei HC, Chu KH. 2011. Molecular systematics of caridean shrimps based on five nuclear genes: implications for superfamily classification. Zoologischer Anzeiger 250: 270-279.

Meyer, R. Lehmanna T, Melzera RR, Geiselbrech H. 2014. Morphology of the first zoeal stage of the Mediterranean bumblebee shrimp Gnathophyllum elegans studied with both light microscopy and scanning EM. Journal of the Marine Biological Association of the United Kingdom 94:151-158.

Mitsuhashi M, Sin YW, Lei HC, Chan TY, Chu KH. 2007. Systematic status of the caridean families Gnathophyllidae Dana and Hymenoceridae Ortmann (Crustacea : Decapoda): a 
preliminary examination based on nuclear rDNA sequences. Invertebrate Systematics 21: 613-622.

551

552

Page TJ, Short JW, Humphrey CJ, Hillyer MJ, Hughes JM. 2008. Molecular systematics of the Kakaducarididae (Crustacea: Decapoda: Caridea). Molecular Phylogenetics and Evolution 46: 1003-1014.

Ronquist F, Teslenko M, van der Mark P, Ayres DL, Darling A, Hohna S, Larget B, Liu L, Suchard MA, Huelsenbeck JP. 2012. MrBayes 3.2: efficient Bayesian phylogenetic inference and model choice across a large model space. Systematic Biology 61: 539-542.

Short JW, Humphrey CL, Page TJ. 2013. Systematic revision and reappraisal of the Kakaducarididae Bruce (Crustacea: Decapoda: Caridea) with the description of three new species of Leptopalaemon Bruce \& Short. Invertebrate Systematics 27: 87-117.

Sollaud E. 1910. Sur les affinités des genres Urocaris (Stimpson) et Palaemonella (Dana), et consideration sur l'evolution des crevettes de la famille Pontoniides. Comptes Rendus de l'Academie des Sciences, Paris 151: 1158-1161.

Spence Bate C. 1888. Report on the Crustacea Macrura collected by the Challenger during the years 1873-76. Report on the Scientific Results of the Voyage of H.M.S. "Challenger" during the years 1873-76 24: i-xc-1-942, Plates 1-157.

Tamura K, Stecher G, Peterson D, Filipski A, Kumar S. 2013. MEGA6: Molecular Evolutionary Genetics Analysis version 6.0. Molecular Biology and Evolution 30: 2725-2729.

Watling L. 1989. A classification system for crustacean setae based on the homology concept. In: Felgenhauer BE, Watling L, Thistle AB, eds. Functional morphology of feeding and grooming in Crustacea. Rotterdam: A.A. Balkema. 15-26.

Wicksten MK. 2010. Infraorder Caridea Dana, 1852. In: Schram FJ, von Vaupel Klein JC, eds. Treatise on Zoology - Anatomy, Taxonomy, Biology. The Crustacea. Volume 9, part A. Eucarida: Euphausiacea, Amphionidacea, and Decapoda (partim). Leiden: Brill, 165206.

Wong ML, Pérez-Moreno JL, Chan TY, Frank TM, Bracken-Grissom HD. 2015. Phylogenetic and transcriptomic analyses reveal the evolution of bioluminescence and light detection in marine deep-sea shrimps of the family Oplophoridae (Crustacea: Decapoda). Molecular Phylogenetics and Evolution 83: 278-292. 
Figures

581 Figure 1. Bayesian majority rule consensus topology for combined dataset $(16 \mathrm{~S} / \mathrm{H} 3 / 18 \mathrm{~S})$ of the palaemonoid clade. No constraints, only clades with $>0.50$ posterior probability are shown, Tree Score $=-16540.11$. For definitions of palaemonid clades, see text.

Figure 2. Ornamentation of the posterior telson margin of some Palaemoninae. A: Palaemon median setae; E: Leander tenuicornis, F: Palaemon modestus. Scale bars indicate $100 \mu \mathrm{m}(\mathrm{A}, \mathrm{C}$,

Figure 3. Ornamentation of the posterior telson margin of some Pontoniinae. A: Palaemonella rotumana, B: same, detail of median setae; C: Cuapetes americanus, D, detail of median setae; E: Periclimenes brevicarpalis; F: Periclimenaeus caraibicus. Scale bars indicate $100 \mu \mathrm{m}(\mathrm{A}, \mathrm{C}$, E), $50 \mu \mathrm{m}(\mathrm{B}, \mathrm{F})$ or $20 \mu \mathrm{m}(\mathrm{D})$.

Figure 4. Ornamentation of the posterior telson margin of some Pontoniinae. A: Jocaste lucina, B: same, detail of median setae; C: Thaumastocaris streptopus, D: same, detail of median setae; E: Stegopontonia commensalis; F: Conchodytes nipponensis. Scale bars indicate $100 \mu \mathrm{m}(\mathrm{A}, \mathrm{C}$, F), $20 \mu \mathrm{m}(\mathrm{E})$ or $10 \mu \mathrm{m}(\mathrm{B}, \mathrm{D})$.

599

Figure 5. Cladogram of hypothesised relationships of palaemonoid taxa derived from all molecular analyses. Thicker lines denote where evidence is stronger.

602

603

604

\section{Supplementary figures}

605 Supplementary Figure 1. Bayesian majority rule consensus topology for combined dataset

606 (16S/H3/18S) of the palaemonoid clade. Constraint B (Palaemoninae species form a clade and

607 species of Pontoniinae, Gnathophyllidae, and Hymenoceridae form a clade) (clades with $>0.50$

608 posterior probability shown) (Tree Score $=-16546.48$ ).

609

610 Supplementary Figure 2. Bayesian majority rule consensus topology for combined dataset 611 (16S/H3/18S) of the palaemonoid clade. Constraint C (species of Palaemoninae, Pontoniinae, 612 Gnathophyllidae and Hymenoceridae all form a clade) (clades with $>0.50$ posterior probability

613 shown) (Tree Score $=-16540.26)$.

614

Supplementary Figure 3. Maximum Likelihood majority rule consensus topology for 16S dataset of the palaemonoid clade $($ Tree Score $=-7434.59)$. palaemonoid clade $($ Tree Score $=-8098.11)$.

Supplementary Figure 5. Maximum Likelihood majority rule consensus topology for H3 dataset

623 of the palaemonoid clade (Tree Score $=-3329.51)$.

625

Supplementary Figure 6. Bayesian majority rule consensus topology for $\mathrm{H} 3$ dataset of the palaemonoid clade (Tree Score $=-3364.55)$. 
627 Supplementary Figure 7. Maximum Likelihood majority rule consensus topology for $18 \mathrm{~S}$ dataset 628 of the palaemonoid clade (Tree Score $=-4812.79$ ).

629

630 Supplementary Figure 8. Bayesian majority rule consensus topology for 18S dataset of the 631 palaemonoid clade (Tree Score $=-4859.85$ ).

632

633

634 


\author{
Table 1 (on next page) \\ Details of sequences used in this study.
}


Table 1 Details of sequences used in this study.

\begin{tabular}{|c|c|c|c|}
\hline & \multicolumn{3}{|c|}{ GenBank Accession Numbers } \\
\hline & $16 \mathrm{~S}$ & $\mathrm{H} 3$ & $18 \mathrm{~S}$ \\
\hline \multicolumn{4}{|l|}{ Anchistioididae } \\
\hline Anchistioides antiguensis (Schmitt, 1924) & EU920911 & EU921043 & EU920936 \\
\hline Anchistioides willeyi (Borradaile, 1900) & KC515030 & KC515074 & - \\
\hline \multicolumn{4}{|l|}{ Desmocarididae } \\
\hline Desmocaris sp. & EU868651 & - & EU868742 \\
\hline \multicolumn{4}{|l|}{ Euryrhynchidae } \\
\hline Euryrhynchus wrzesniowskii Miers, 1877 & EU868654 & - & EU868745 \\
\hline \multicolumn{4}{|l|}{ Gnathophyllidae } \\
\hline Gnathophylloides mineri Schmitt, 1933 & EU868659 & KT224392 & EU868750 \\
\hline Gnathophyllum americanum Guérin-Meneville, 1855 & EU868660 & JF346317 & EU868751 \\
\hline \multicolumn{4}{|l|}{ Hymenoceridae } \\
\hline Hymenocera picta Dana, 1852 & EU868663 & JF346328 & EU868754 \\
\hline Phyllognathia ceratophthalma (Balss, 1913) & KC515032 & KC515076 & DQ642847 \\
\hline \multicolumn{4}{|l|}{ Palaemonidae - Palaemoninae } \\
\hline Arachnochium mirabilis (Kemp, 1917) & KC515033 & KC515077 & KC515052 \\
\hline Brachycarpus biunguiculatus (Lucas, 1846) & EU868684 & JN674391 & EU868779 \\
\hline Creaseria morleyi (Creaser, 1936) & EU868688 & DQ079671 & DQ079746 \\
\hline Cryphiops caementarius (Molina, 1782) & DQ079711 & DQ079672 & DQ079747 \\
\hline Leander tenuicornis (Say, 1818) & EU868690 & JN674388 & EU868783 \\
\hline Leandrites deschampsi (Nobili, 1903) & KC515039 & KC515081 & - \\
\hline Leptocarpus potamiscus (Kemp, 1917) & JN674328 & JN674392 & - \\
\hline Macrobrachium rosenbergii (De Man, 1879) & FM986637 & FM958123 & DQ642856 \\
\hline Nematopalaemon tenuipes (Henderson, 1893) & KC515042 & JN674382 & - \\
\hline Palaemon concinnus Dana, 1852 & KC515043 & KC515085 & KC515056 \\
\hline Palaemon elegans Rathke, 1837 & EU868696 & DQ079696 & DQ079764 \\
\hline Palaemon pandaliformis (Stimpson, 1871) & JN674341 & JN674364 & - \\
\hline Urocaridella pulchella Yokes \& Galil, 2006 & KC515050 & KC515092 & KC515062 \\
\hline \multicolumn{4}{|l|}{ Palaemonidae - Pontoniinae } \\
\hline Anchiopontonia hurii (Holthuis, 1961) & KF738358 & KF738309 & - \\
\hline Anchistus custos (Forskål, 1775) & KF738360 & KF738311 & - \\
\hline Conchodytes meleagrinae Peters, 1852 & KC515051 & KC515093 & EF540837 \\
\hline Coralliocaris graminea (Dana, 1852) & KF738361 & KF738313 & AM083319 \\
\hline Cuapetes andamanensis (Kemp, 1922) & JX025214 & KF738315 & - \\
\hline Cuapetes elegans (Paulson, 1875) & JX025213 & KF738316 & - \\
\hline Dactylonia ascidicola (Borradaile, 1898) & KF738363 & KF738317 & - \\
\hline Harpiliopsis spinigera (Ortmann, 1890) & JX025206 & KF738319 & - \\
\hline Harpilius lutescens Dana, 1852 & JX025205 & KF738320 & - \\
\hline Ischnopontonia lophos (Barnard, 1962) & KF738364 & KF738321 & \\
\hline Laomenes nudirostris (Bruce, 1968) & KF738366 & KF738323 & - \\
\hline Manipontonia psamathe (De Man, 1902) & JX025199 & KT224393 & - \\
\hline Palaemonella spinulata Yokoya, 1936 & KF738367 & KF738325 & - \\
\hline
\end{tabular}




\begin{tabular}{|l|c|c|c|}
\hline Periclimenaeus bidentatus Bruce, 1970 & KF738368 & KF738326 & - \\
\hline Periclimenes brevicarpalis (Schenkel, 1902) & JX025191 & JF346324 & JF346254 \\
\hline Periclimenes calcaratus Chace \& Bruce, 1993 & KF738370 & KF738329 & - \\
\hline Philarius gerlachei (Nobili, 1905) & JX025177 & KF7383333 & - \\
\hline Platycaris latirostris Holthuis, 1952 & KF738371 & KF738335 & - \\
\hline Pliopontonia furtiva Bruce, 1973 & KF738372 & KF738336 & - \\
\hline Pontonia manningi Fransen, 2000 & EU868705 & KT224394 & EU868800 \\
\hline Thaumastocaris streptopus Kemp, 1922 & KF738373 & KF738337 & DQ642852 \\
\hline Zenopontonia soror (Nobili, 1904) & JX025178 & KF738332 & - \\
\hline Typhlocarididae & & & \\
\hline Typhlocaris salentina Caroli, 1923 & EU868713 & - & EU868808 \\
\hline Alpheidae & & & \\
\hline Betaeus longidactylus Lockington, 1877 & JX010752 & JX010771 & JF346263 \\
\hline
\end{tabular}




\section{Table 2 (on next page)}

Species examined by SEM for morphology of telson setation (all material is accessioned in the Oxford University Museum of Natural History-OUMNH.ZC). 
1 Table 2 Species examined by SEM for morphology of telson setation (all material is accessioned 2 in the Oxford University Museum of Natural History-OUMNH.ZC).

3

4

\begin{tabular}{|l|l|l|}
\hline & Origin & Accession number \\
\hline Palaemonidae - Palaemoninae & & \\
\hline Leander tenuicornis (Say, 1818) & USA & OUMNH.ZC.2006-11-007 \\
\hline Macrobrachium amazonicum (Heller, 1862) & Brazil & OUMNH.ZC.2002-27-003 \\
\hline Palaemon adspersus Rathke, 1837 & Greece & OUMNH.ZC.2003-03-001 \\
\hline Palaemon modestus (Heller, 1862) & Kazahkstan & OUMNH.ZC.2012-01-068 \\
\hline Palaemonidae - Pontoniinae & & \\
\hline Conchodytes nipponensis (De Haan, 1844) & Japan & OUMNH.ZC.2011-11-001 \\
\hline Cuapetes americanus (Kingsley, 1878) & Panama & OUMNH.ZC.2003-33-050 \\
\hline Jocaste lucina (Nobili, 1901) & Chagos & OUMNH.ZC.2014-09-038 \\
\hline Palaemonella rotumana (Borradaile, 1898) & Singapore & OUMNH.ZC.2011-02-003 \\
\hline Periclimenaeus caraibicus Holthuis, 1951 & Panama & OUMNH.ZC.2008-14-065 \\
\hline Periclimenes brevicarpalis (Schenkel, 1902) & Taiwan & OUMNH.ZC.2010-02-003 \\
\hline Stegopontonia commensalis Nobili, 1906 & Taiwan & OUMNH.ZC.2010-02-039 \\
\hline Thaumastocaris streptopus Kemp, 1922 & Israel & OUMNH.ZC.2011-05-024 \\
\hline
\end{tabular}

5 
Table 3(on next page)

Datasets, molecular models and tree scores for analyses conducted in this study 
Table 3. Datasets, molecular models and tree scores for analyses conducted in this study

\begin{tabular}{|c|c|c|c|c|c|c|}
\hline Dataset & $\begin{array}{l}\text { Molecular } \\
\text { model }\end{array}$ & $N$ & Figure & Tree Scores & $\begin{array}{c}\text { Difference } \\
\text { versus } \\
\text { unconstraint }\end{array}$ & BF strength of evidence of difference \\
\hline 16S/H3/18S (Combined) & & 45 & & & & \\
\hline Constraint A & & & & -16617.59 & 77.48 & very strong against \\
\hline Constraint B & & & S1 & -16546.48 & 6.37 & very strong against \\
\hline Constraint $\mathrm{C}$ & & & S2 & -16540.26 & 0.15 & equivocal \\
\hline Constraint $\mathrm{F}$ & & & & -16547.56 & 7.45 & very strong against \\
\hline Constraint $\mathrm{G}$ & & & & -16545.17 & 5.06 & very strong against \\
\hline 16S rDNA (16S) & $\mathrm{TN} 93+\mathrm{G}+\mathrm{I}$ & 45 & & & & \\
\hline Unconstrained ML & & & S3 & -7434.59 & & \\
\hline Unconstrained ML & & & S5 & -3329.51 & & \\
\hline Unconstrained BA & & & S6 & -3364.55 & & \\
\hline Constraint $\mathrm{A}$ & & & & -3386.06 & 21.51 & very strong against \\
\hline Constraint B & & & & -3371.81 & 7.26 & very strong against \\
\hline 18S rDNA (18S) & $\mathrm{K} 2+\mathrm{G}+\mathrm{I}$ & 23 & & & & \\
\hline Unconstrained ML & & & S7 & -4812.79 & & \\
\hline Unconstrained BA & & & S8 & -4859.85 & & \\
\hline Constraint A & & & & -4907.84 & 47.99 & very strong against \\
\hline Constraint B & & & & -4872.23 & 12.38 & very strong against \\
\hline
\end{tabular}

3 Abbreviations: BA, Bayesian analysis; BF, Bayes Factor; G, Gamma Rate Distribution; I, Invariant sites; K2 Kimua 2-parameter; ML,

4 Maximum Likelihood; TN93, Tamara-Nei model. 


\section{PeerJ Reviewing Manuscript}


Bayesian majority rule consensus topology for combined dataset $(16 \mathrm{~S} / \mathrm{H} 3 / 18 \mathrm{~S})$ of the palaemonoid clade

No constraints, only clades with $>0.50$ posterior probability are shown, Tree Score $=$ -

16540.11. For definitions of palaemonid clades, see text.

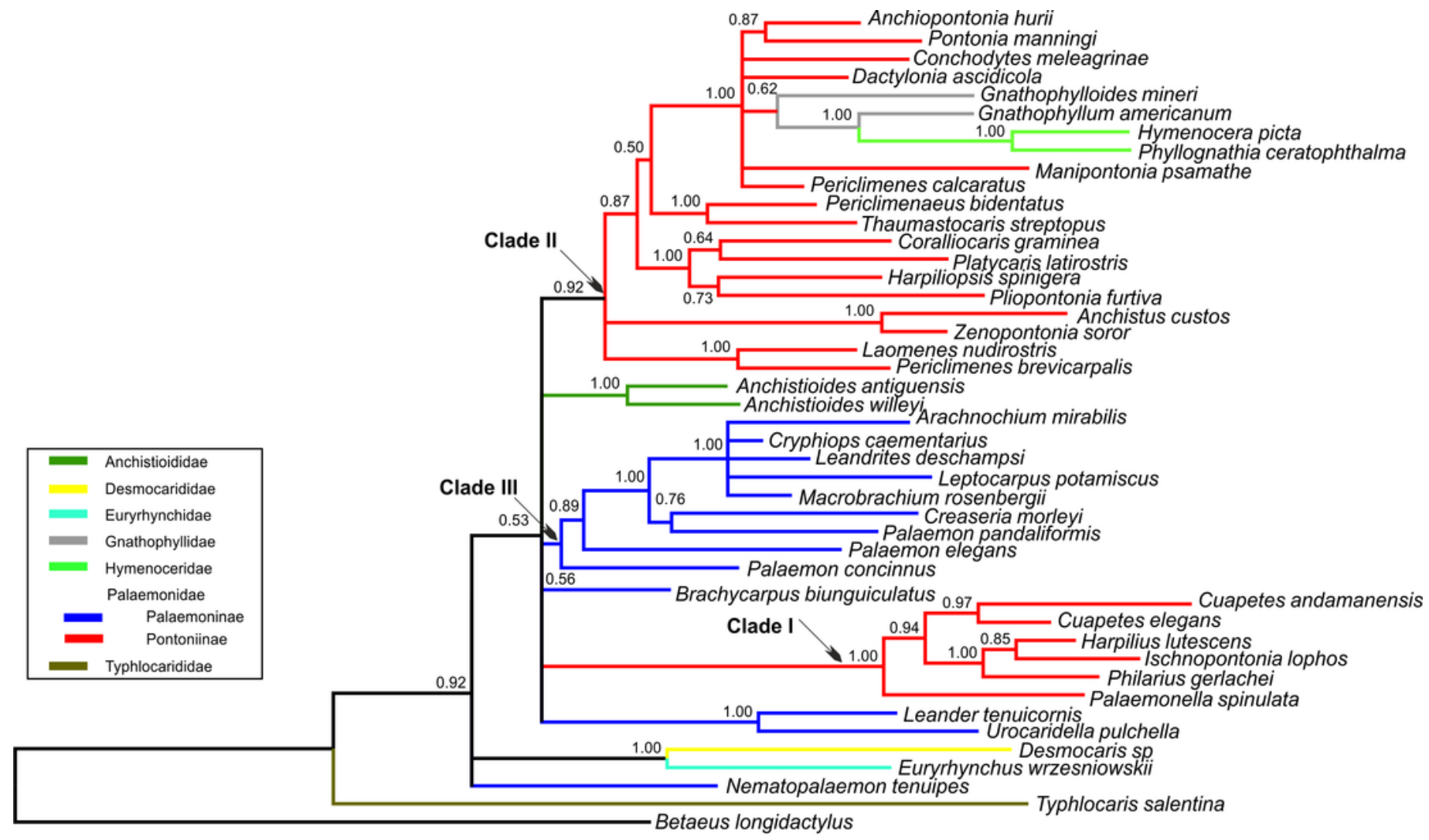


2

Ornamentation of the posterior telson margin of some Palaemoninae.

A: Palaemon adspersus; B: same, detail of median setae; C: Macrobrachium amazonicum; D; same, detail of median setae; E: Leander tenuicornis, F: Palaemon modestus. Scale bars indicate $100 \mu \mathrm{m}$ (A, C, D-E), $40 \mu \mathrm{m}$ (B) or $20 \mu \mathrm{m}$ (D). 
PeerJ Reviewing Manuscript

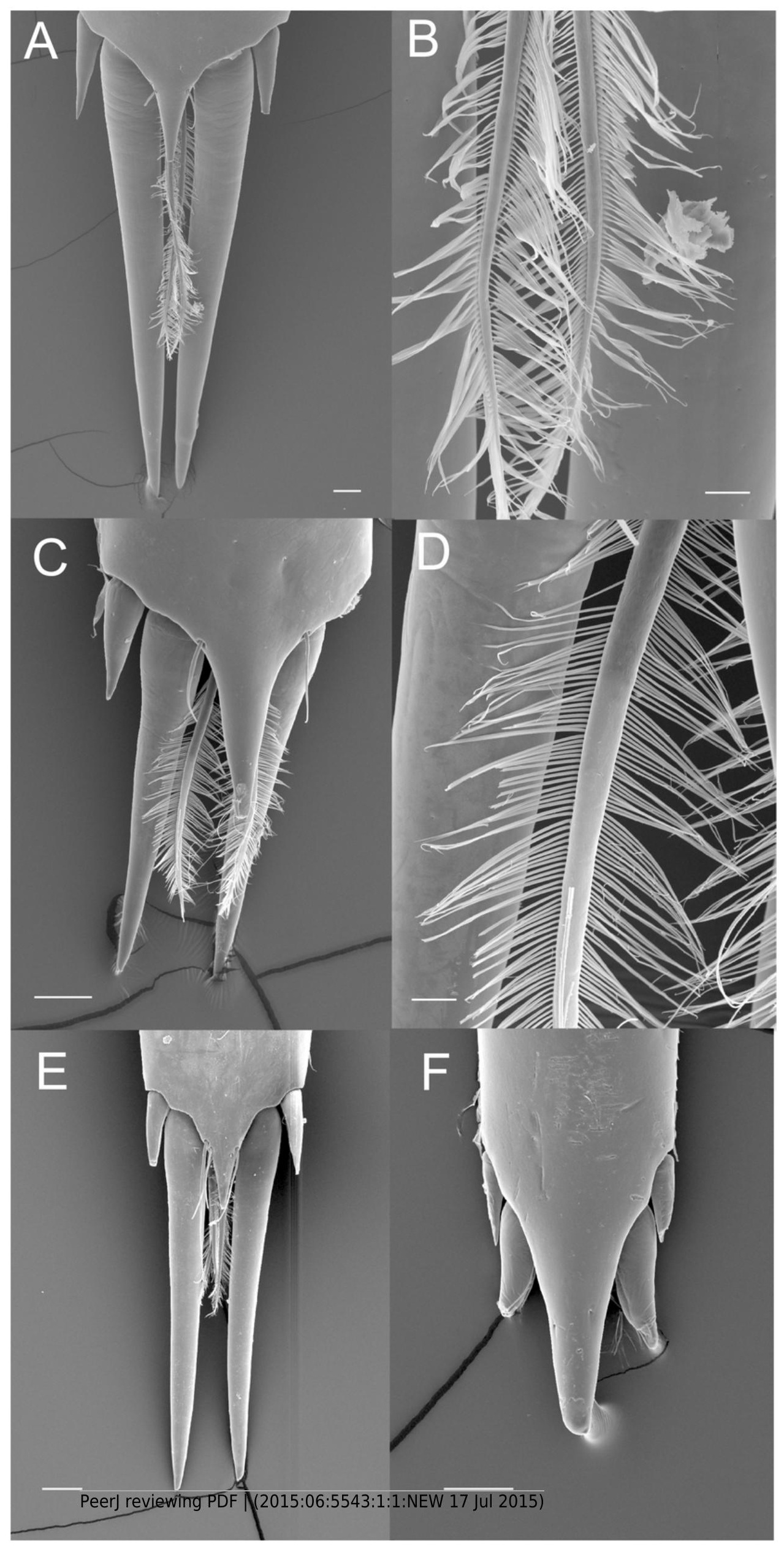


3

Ornamentation of the posterior telson margin of some Pontoniinae.

A: Palaemonella rotumana, B: same, detail of median setae; C: Cuapetes americanus, D, detail of median setae; E: Periclimenes brevicarpalis; F: Periclimenaeus caraibicus. Scale bars indicate $100 \mu \mathrm{m}$ (A, C, E), $50 \mu \mathrm{m}$ (B, F) or $20 \mu \mathrm{m}$ (D). 
PeerJ Reviewing Manuscript

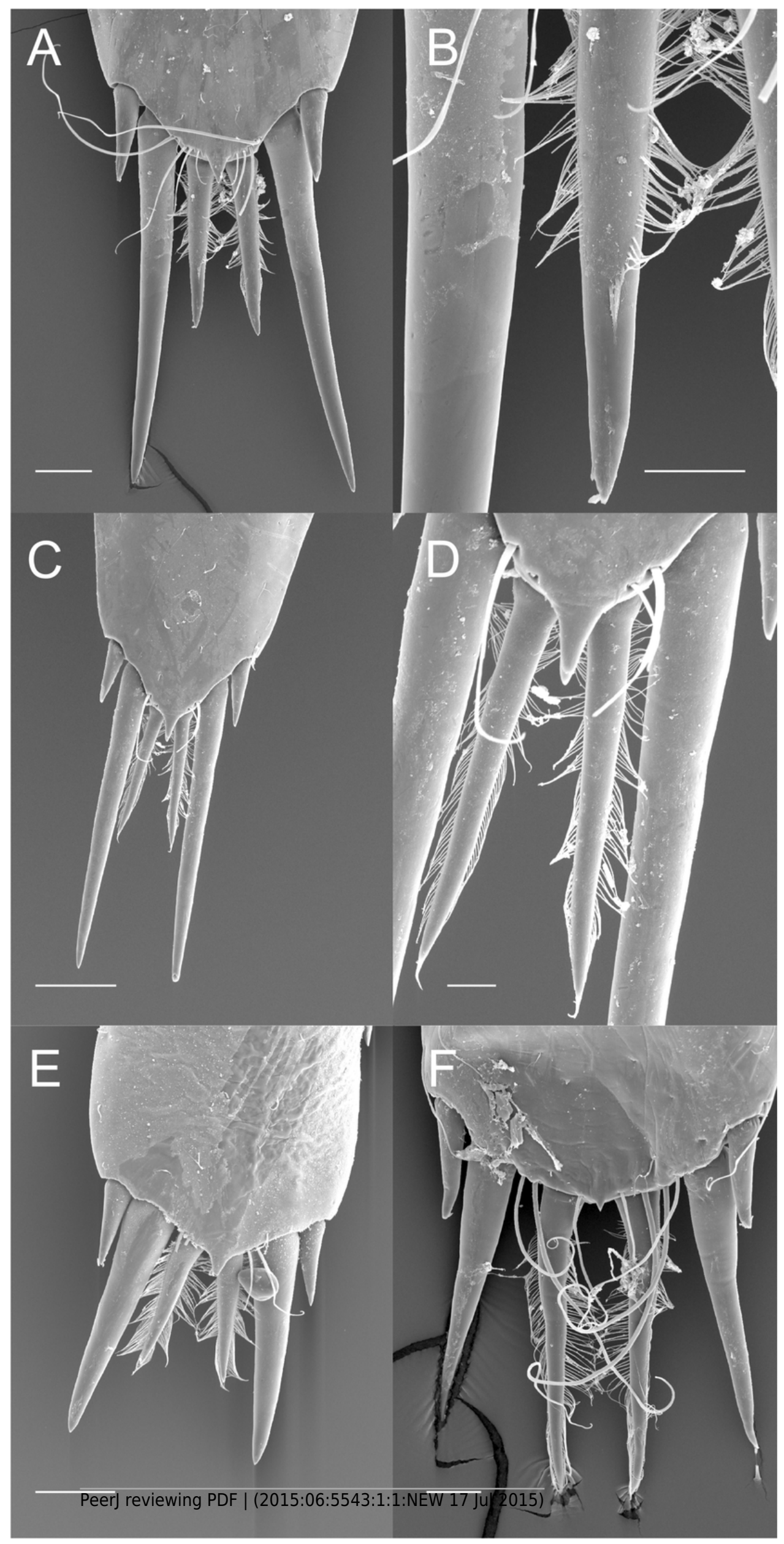


4

Ornamentation of the posterior telson margin of some Pontoniinae.

A: Jocaste lucina, B: same, detail of median setae; C: Thaumastocaris streptopus, D: same, detail of median setae; E: Stegopontonia commensalis; F: Conchodytes nipponensis. Scale bars indicate $100 \mu \mathrm{m}(\mathrm{A}, \mathrm{C}, \mathrm{F}), 20 \mu \mathrm{m}(\mathrm{E})$ or $10 \mu \mathrm{m}(\mathrm{B}, \mathrm{D})$. 
PeerJ Reviewing Manuscript

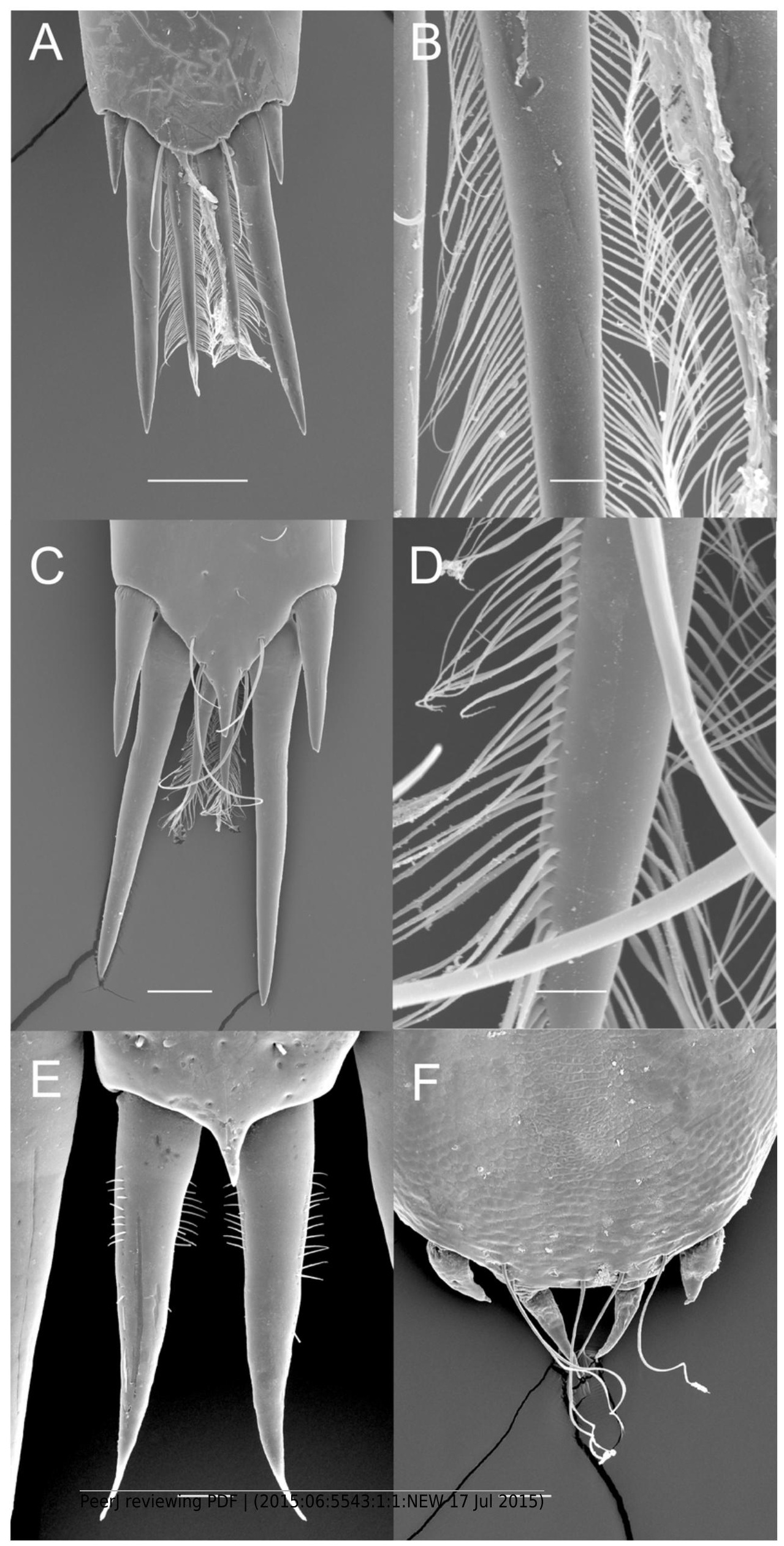




\section{5}

Cladogram of hypothesised relationships of palaemonoid taxa derived from all molecular analyses.

Thicker lines denote where evidence is stronger.

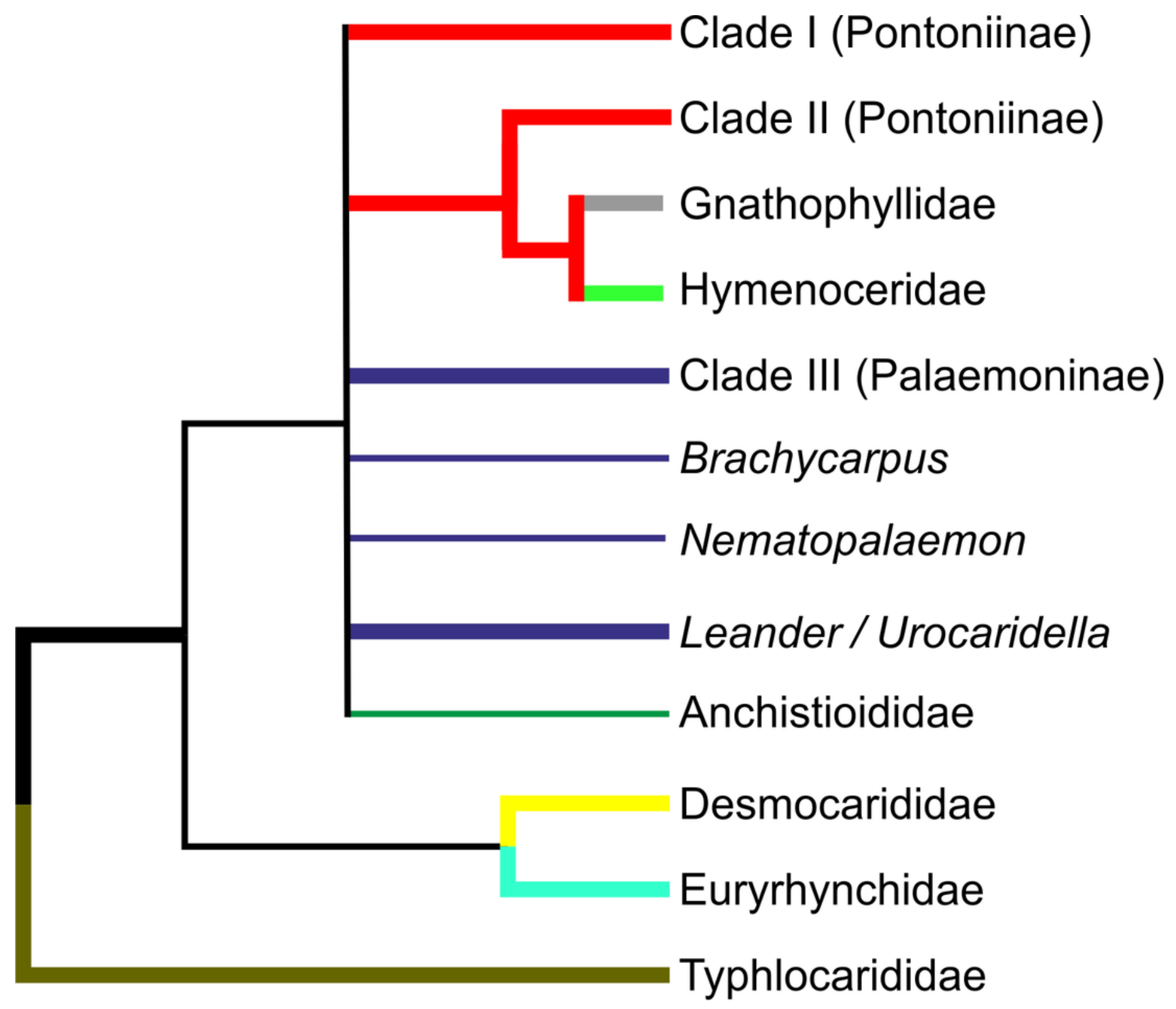

